\title{
Response of an endangered tree species from Caatinga to mycorrhization and phosphorus fertilization
}

\author{
João Ricardo Gonçalves de Oliveira ${ }^{1}$, Eliene Matos e Silva ${ }^{1}$, Thaís Teixeira-Rios ${ }^{1}$, \\ Natoniel Franklin de Melo² and Adriana Mayumi Yano-Melo ${ }^{3,4}$
}

Received: November 11, 2013. Accepted: September 15, 2014

\begin{abstract}
Schinopsis brasiliensis is an endangered tree species found in the Caatinga biome. It presents a characteristic slow development and difficult propagation, although it has been traditionally exploited in the region. Application of arbuscular mycorrhizal fungi (AMF) and phosphorus (P) fertilization may be beneficial to S. brasiliensis development at the seedling stage, which at the same time may help species conservation and the recovery of degraded areas in the Caatinga biome. We assessed the response of $S$. brasiliensis to AMF inoculation (Claroideoglomus etunicatum and Acaulospora longula) and $\mathrm{P}$ fertilization $\left(0,12,24\right.$, and $48 \mathrm{mg} \mathrm{dm}^{-3}$ addition of $\left.\mathrm{P}_{2} \mathrm{O}_{5}\right)$. S. brasiliensis responded positively to both AMF inoculation and P fertilization. At low $\mathrm{P}$ concentrations, the inoculated plants showed higher leaf area and enhanced vegetative development, nutrient content and biomass production compared with non-inoculated plants. Conversely, increasing levels of $\mathrm{P}$ fertilization decreased the level of mycorrhizal colonization, plant responsiveness to inoculation, and spore production in C. etunicatum. Thus, P concentrations were able to influence the response of S. brasiliensis to mycorrhization and responsiveness to increased mycorrhization with the decrease in $\mathrm{P}$ availability. These results showed that mycorrhizal symbiosis plays an essential role in the development of S. brasiliensis.
\end{abstract}

Keywords: arbuscular mycorrhizal fungi, native plants, nutrient concentration, seedling production, semiarid area

\section{Introduction}

Caatinga is the only biome exclusive to Brazil. This biome occupies approximately $10 \%$ of the entire Brazilian territory $\left(844.453 \mathrm{~km}^{2}\right)$ and is the dominant biome $(54 \%)$ in the northeast region. The Caatinga is a region rich in habitats and species; however, it is also exposed to anthropogenic pressures and intensive exploitation of the native vegetation. As a consequence, the soil has gradually lost regeneration potential, which has become increasingly apparent over the past few years. However, despite this issue currently affecting approximately $70 \%$ of the biome's original area and causing invaluable losses to the biological richness (Tabarelli \& Silva 2003), no specific conservation plans are in place to mitigate it.

Not all forest plant species are able to colonize and establish in degraded soils, mainly due to low nutrient acquisition as a consequence of low nutrient availability in these soils (Sugai et al. 2010). Native Caatinga plant species are known to present this type of limitation (Andrade et al. 2009); in addition, many of them are subjected to exploitation due to their multiple traditional uses. This is the case of the tree species Schinopsis brasiliensis (Santos et al. 2008); this species is considered a secondary succession species of the Caatinga biome (Carvalho et al. 2012), listed as an endangered species in Brazil (Oliveira et al. 2007).

A possible way to circumvent these difficulties and to conserve Caatinga plant resources is through the use of symbiotic microorganisms, such as arbuscular mycorrhizal fungi (AMF), which plays a key role in ecosystem maintenance (Heijden et al. 1998). Mycorrhization increases the absorption area around the root by increasing the area of the surface in contact with the soil, increasing the absorption of mineral nutrients, such as phosphorus, zinc, copper, nitrogen, and potassium. This higher nutrient acquisition directly influences plant growth and tolerance to environmental stresses (Smith \& Read 2008), such as drought stress (Zhu et al. 2012), typical of the semiarid environment of Caatinga biome.

Approximately 80 species of AMF are known from Caatinga (Goto et al. 2010). Some isolates from the region

\footnotetext{
${ }^{1}$ Universidade Federal de Pernambuco, Centro de Ciências Biológicas, Departamento de Micologia, Rua Nelson Chaves, s/n, Cidade Universitária, CEP 50670-420, Recife, PE, Brazil.

${ }^{2}$ Embrapa Semiárido, Laboratório de Biotecnologia, Caixa Postal 23, CEP 56302-970, Petrolina, PE, Brazil.

${ }^{3}$ Universidade Federal do Vale do São Francisco, Campus de Ciências Agrárias, Rodovia BR 407, Km 12, Lote 543, Projeto de Irrigação Nilo Coelho, s/n, "C1", CEP 56300-990, Petrolina, PE, Brazil.

${ }^{4}$ Author for correspondence: amymelo17@hotmail.com
} 
have shown tolerance to environmental stress (Teixeira-Rios et al. 2013); however, little is known about the contribution of this symbiosis to the survival and development of native plants in semiarid environments (Maia et al. 2010).

Native tree species able to interact with AMF are of great importance in the recovery of degraded areas and in reforestation with economically important species because the majority of the areas destined for reforestation are nutrientpoor, which can prevent successful seedling establishment and early development (Sugai et al. 2010). The only studies focused on Caatinga native plant species showed that plant development of most plant species could be enhanced by inoculation with AMF or Rhizobium spp. and/or phosphorus $(\mathrm{P})$ fertilization. These treatments, alone or in combination, have been shown to enhance shoot and root seedling biomass of Anadenanthera macrocarpa (Sugai et al. 2010), Campomanesia cambessedeana, Hymenaea courbaril, Inga laurina, and Sterculia striata (Lacerda et al. 2011).

There is a need to search and implement sustainable strategies for the use of Caatinga natural resources and native flora, particularly for endangered species. Thus, seedlings production technologies could be a suitable alternative for reducing costs and time by growing high quality plants more likely to succeed in degraded soils. Due to the benefits associated with AMF inoculation, mainly in nutrient-poor soils, the goal of the present study was to evaluate the response of S. brasiliensis seedlings to AMF inoculation and $\mathrm{P}$ fertilization on the initial growth stages and soil nutrient concentrations.

\section{Materials and methods}

\section{Experimental conditions and design}

The experiment was performed under controlled conditions in a glasshouse located in Petrolina (PE). The soil used (Ultisol) had the following characteristics: $\mathrm{pH}=5.8$; E.C. (electrical conductivity) $=0.51 \mathrm{dS} \mathrm{m}^{-1} ; \mathrm{P}=6.14 \mathrm{mg} \mathrm{dm}^{-3}$; potassium $(\mathrm{K})=0.35 \mathrm{cmol}_{\mathrm{c}} \mathrm{dm}^{-3} ;$ calcium $(\mathrm{Ca})=1.5$ $\mathrm{cmol}_{\mathrm{c}} \mathrm{dm}^{-3}$; magnesium $(\mathrm{Mg})=1 \mathrm{cmol}_{\mathrm{c}} \mathrm{dm}^{-3}$; sodium $(\mathrm{Na})$ $=0.03 \mathrm{cmol}_{c} \mathrm{dm}^{-3}$; aluminum $(\mathrm{Al})=0.1 \mathrm{cmol}_{c} \mathrm{dm}^{-3}$; CTC (cation-exchange capacity) $=7.5 \mathrm{cmol}_{c} \mathrm{dm}^{-3}$ and $10.96 \mathrm{~g} \mathrm{~kg}^{-1}$ organic matter. This soil was not limed. All soil chemical properties were characterized before sterilization and the addition of phosphorus.

The soil was autoclaved 3 times on 3 consecutive days, for $1 \mathrm{~h}$ at $121^{\circ} \mathrm{C}$ and left without treatment for 15 days. $\mathrm{P}$ was subsequently added to the soil as single superphosphate $\left(\mathrm{P}_{2} \mathrm{O}_{5}\right)$ and thoroughly mixed with the soil. $\mathrm{P}$ was added at different quantities depending on the treatment, and the soil-P mixture was placed in bags with a capacity of $2.0 \mathrm{~kg}$. The experiment followed a completely randomized design with a $3 \times 4$ factorial scheme, with 3 inoculation treatments: Control (non-inoculated); Claroideoglomus etunicatum [Becker \& Gerd.] C. Walker \& A. Schüssler
(UNIVASF06) and Acaulospora longula Spain \& Schenck (UNIVASF12), 4 levels of added $\mathrm{P}$ [0 (no $\mathrm{P}_{2} \mathrm{O}_{5}$ addition), 12 , 24, and $48 \mathrm{mg} \mathrm{dm}^{-3} \mathrm{P}_{2} \mathrm{O}_{5}$, and 10 replicates. The soil without additional $\mathrm{P}$ was considered as natural soil fertility, containing $6.15 \mathrm{mg} \mathrm{dm}^{-3} \mathrm{P}$ (hereafter, treatment $\mathrm{P} 6$ ). The remaining treatments were designated as P12, P24, and P48.

Mycorrhizal isolates and Schinopsis brasiliensis Engl. Seedlings

C. etunicatum (UNIVASF06) and A. longula (UNIVASF12) isolates were obtained from the Univasf inoculum bank and propagated into pots containing previously sterilized sand:soil $(1: 1 \mathrm{v} / \mathrm{v})$ with sorghum as the host plant (Sorghum bicolor [L.] Moench.) maintained in a glasshouse. The spores produced by the inoculum were extracted by wet sieving and decanting (Gerdemann \& Nicolson 1963), followed by water and sucrose $(40 \% \mathrm{w} / \mathrm{v})$ centrifugation (Jenkins 1964). The number of spores was quantified in Petri dishes scribed with parallel lines, using a stereomicroscope $(40 \times)$. The amount of inoculum used was determined based on number of spores contained by the inoculum. The inoculum comprised soil, mycorrhizal mycelium, colonized root fragments, and approximately 200 glomerospores placed below the plant roots.

S. brasiliensis seedlings were germinated from seeds whose tegument had been previously cut in the region opposite to the embryo. The seeds were surface-sterilized with sodium hypochlorite $(0.05 \%$ active chlorine $\mathrm{v} / \mathrm{v}$ ) for $15 \mathrm{~min}$, rinsed with distilled water and sown in trays containing vermiculite. Seedlings with three leaves were transferred to bags previously filled with inoculated and P-fertilized soil.

\section{Data collection}

Height, number of leaves, and stem diameter were measured every two weeks during growth in the glasshouse. After 135 days, we measured the percentage of seedling survival, leaf area, shoot and root fresh and dry weights, mycorrhizal colonization, and number of spores per pot. To determine dry weight, $S$. brasiliensis leaf and root samples were placed in an oven at $65^{\circ} \mathrm{C}$ until a constant weight was reached. Following weighting, shoot samples were homogenized using a Willey mill. Further, aliquots of $0.5 \mathrm{~g}$ of each sample were mineralized by nitric-perchloric acid digestion and used for elemental analysis. $\mathrm{Ca}$, sulfur $(\mathrm{S}), \mathrm{Mg}$, iron $(\mathrm{Fe})$, zinc $(\mathrm{Zn})$, copper $(\mathrm{Cu})$, and manganese $(\mathrm{Mn})$ were quantified by atomic absorption spectrometry; $\mathrm{P}$ and boron (B) were quantified by colorimetry, and $\mathrm{K}$ and $\mathrm{Na}$ were quantified by flame photometry. Nitrogen $(\mathrm{N})$ content was quantified by digesting a $0.1 \mathrm{~g}$ aliquot of each sample in sulfuric acid in the presence of selenium dust, copper sulfate, and potassium. All the analyses were performed according to the Embrapa manual for soil, plant, and fertilizer chemical analyses (Silva 1999). 
Mycorrhizal colonization was quantified following the gridline-intersect method as previously described (Giovannetti \& Mosse 1980). Prior to quantification, the roots were cleaned with $10 \% \mathrm{KOH}$, bleached with $10 \% \mathrm{H}_{2} \mathrm{O}_{2}$, acidified with $1 \% \mathrm{HCl}$, and stained with Trypan Blue (0.05\%) (Phillips \& Hayman 1970). The number of spores was counted using the procedures described above (Gerdemann \& Nicolson 1963; Jenkins 1964). Leaf area was estimated using a Li 3100 leaf area meter (LI-Cor Inc. Lincon, Neb., USA). The increment resulting from the different treatments was calculated according to the following equation, adapted from Weber et al. (2004):

$$
\mathrm{I}(\%)=\left[(\mathrm{Tr}-\mathrm{T}) \mathrm{T}^{-1}\right] \times 100
$$

where I (\%) represents variable increment, $\operatorname{Tr}$ is the average value for inoculated plants, and $\mathrm{T}$ is the average value for non-inoculated plants.

The mycorrhizal growth response was calculated according to Janos (2007):

$$
\left[(\mathrm{A}-\mathrm{B}) \mathrm{A}^{-1}\right] \times 100
$$

where A is the dry weight of mycorrhizal plants and B is the dry weight of non-mycorrhizal plants (Plenchette et al. 1983). This response was categorized according to the terminology adapted from the study by Habte \& Manjunath (1991) as very highly responsive (>75\%), highly responsive $(50 \%-70 \%)$, moderately responsive $(25 \%-50 \%)$, marginally responsive $(<25 \%)$ or non-dependent (non-responsive to mycorrhization).

\section{Statistical analyses}

To meet the assumption of homogeneity of variance, spore density data were $\log (x+1)$ transformed, and mycorrhizal colonization data were $\arcsin \left(\sqrt{ }_{\mathrm{x}} / 100\right)$ transformed. A one-way ANOVA, followed by a Tukey's test, was used to test for significant differences among averages at $P \leq 0.05$. A regression was performed for the variables for which significant differences were found among different levels of $\mathrm{P}$ fertilization using the SANEST software (Pelotas, Brasil).

\section{Results and discussion}

Both AMF inoculation and $\mathrm{P}$ addition resulted in an increase in S. brasiliensis vegetative development. A maximal plant survival (100\%) was obtained in most treatments, except for those inoculated with C. etunicatum with P6 and P48, which only reached $90 \%$ survival. Data on plant survival following treatments with different $\mathrm{P}$ levels in glasshouse assays are scarce; however, Carneiro et al. (2004) observed an inverse relationship between survival and increasing $\mathrm{P}$ levels in Cecropia pachystachya plants in a field experiment, with values of $88 \%$ to $25 \%$ from the lowest to the highest $P$ addition.

Mycorrhization increased plant development at the lowest P levels tested. Plant height after 45 days, number of leaves after 60 days, and stem diameter after 75 days differed significantly among $\mathrm{P}$ treatments; these results allowed to determine the best inoculation, and P fertilization treatment to achieve the desired positive effects (data not shown). These patterns were confirmed by subsequent measurements obtained up to 135 days after the beginning of the experiment (Fig. 1A-E), indicating that $\mathrm{P}$ addition influenced positively non-inoculated plants but had a negative effect on the development of mycorrhizal plants. This pattern was particularly obvious in plants associated with C. etunicatum, which were more sensitive to high $\mathrm{P}$ levels (P48). Lacerda et al. (2011) observed a significant effect of $\mathrm{P}$ on stem diameter after 60 days for Dipterix alata and after 90 days for Sterculia striata, Jacaranda cuspidifolia, Inga laurina, and Campomanesia cambessedeana but only for plants inoculated with Glomus clarum.

The beneficial effects that mycorrhization has on plant development could be quantified by calculating the level of $P$ level required for plants to grow to $60 \%$ of their maximum height (Balota et al. 2011b). This index exceeded 60\% for plants grown without additional P (P6) and for those inoculated with AMF. Plant height did not significantly differ between plants with or without mycorrhizal inoculation, only for the highest P level (P48) (Fig. 1A). These results are similar to those observed by previous researchers regarding the response of Barbados nut (Jatropha curcas) plant height (Balota et al. 2011b) to $2.3 \mathrm{mg} \mathrm{kg}^{-1} \mathrm{P}$, acerola (Malpiguia emarginata) (Balota et al. 2011a) plant height response to $5.5 \mathrm{mg} \mathrm{kg}^{-1} \mathrm{P}$ and the response of Acacia mearnsii (Mello et al. 2008) to $8 \mathrm{mg} \mathrm{L}^{-1} \mathrm{P}$.

Previous research assessing the relation between seed weight and the response to mycorrhizal inoculation of plants at different stages of succession showed that larger seeds have greater energy reserves, hence presenting a reduced reliance on mycorrhization at the early stages of development and growth (Pasqualini et al. 2007). Therefore, $S$. brasiliensis seed weight $(0.17 \pm 0.02 \mathrm{~g})$ may have enhanced plant response to mycorrhization.

$\mathrm{P}$ addition positively influenced shoot (SDW) and root (RDW) dry weight in both inoculated and non-inoculated plants (Fig. 1E-F respectively), decelerating plant vegetative development, as indicated by the mycorrhizal growth response. For plants inoculated with C. etunicatum, biomass increment (I) decreased from $1700 \%, 773.33 \%, 183.33 \%$ to $11.54 \%$ SDW and from $580 \%, 369.23 \%, 12 \%$ to $-30 \%$ RDW from the lowest (P6) to P12, P24 and the highest (P48) P levels tested, respectively. In plants inoculated with A. longula, this decrease was less pronounced, from $1360 \%, 907 \%$, $167 \%$ to $47.11 \%$ SDW and from $280 \%, 0.58 \%, 53.50 \%$ to $-10 \%$ RDW, respectively. Mycorrhizal inoculation, P levels and host plant species are known to influence biomass gain in castor bean (Ricinus communis) (Machineski et al. 2011) and plantain (Plantago major) (Freitas et al. 2008).

With the exception of plants inoculated with C. etunicatum in the P48 treatment, all the inoculated plants presented significantly higher leaf areas than the respective 
non-inoculated controls (Fig. 1D). Leaf area increment of mycorrhizal plants was influenced by both mycorrhizal inoculation and $\mathrm{P}$ fertilization. This increment ranged from $2671.6 \%$ to $1.3 \%$ for C. etunicatum inoculated plants and from $2070.7 \%$ to $32.8 \%$ for those inoculated with A. longula from the lowest (P6) to the highest (P48) P levels. Leaf area is directly related to photosynthetic capacity and indicates mycorrhizal symbiosis efficiency (Balota et al. 2011b). Similarly to height, C. etunicatum and A. longula efficiency was inversely proportional to the level of $\mathrm{P}$ added to the soil.

Mycorrhizal colonization and AMF sporulation responded differently to increased P levels (Fig. 2). In both AMF tested, mycorrhizal colonization linearly decreased from the highest to the lowest level of $\mathrm{P}$ added to the soil (Fig. 2A). The
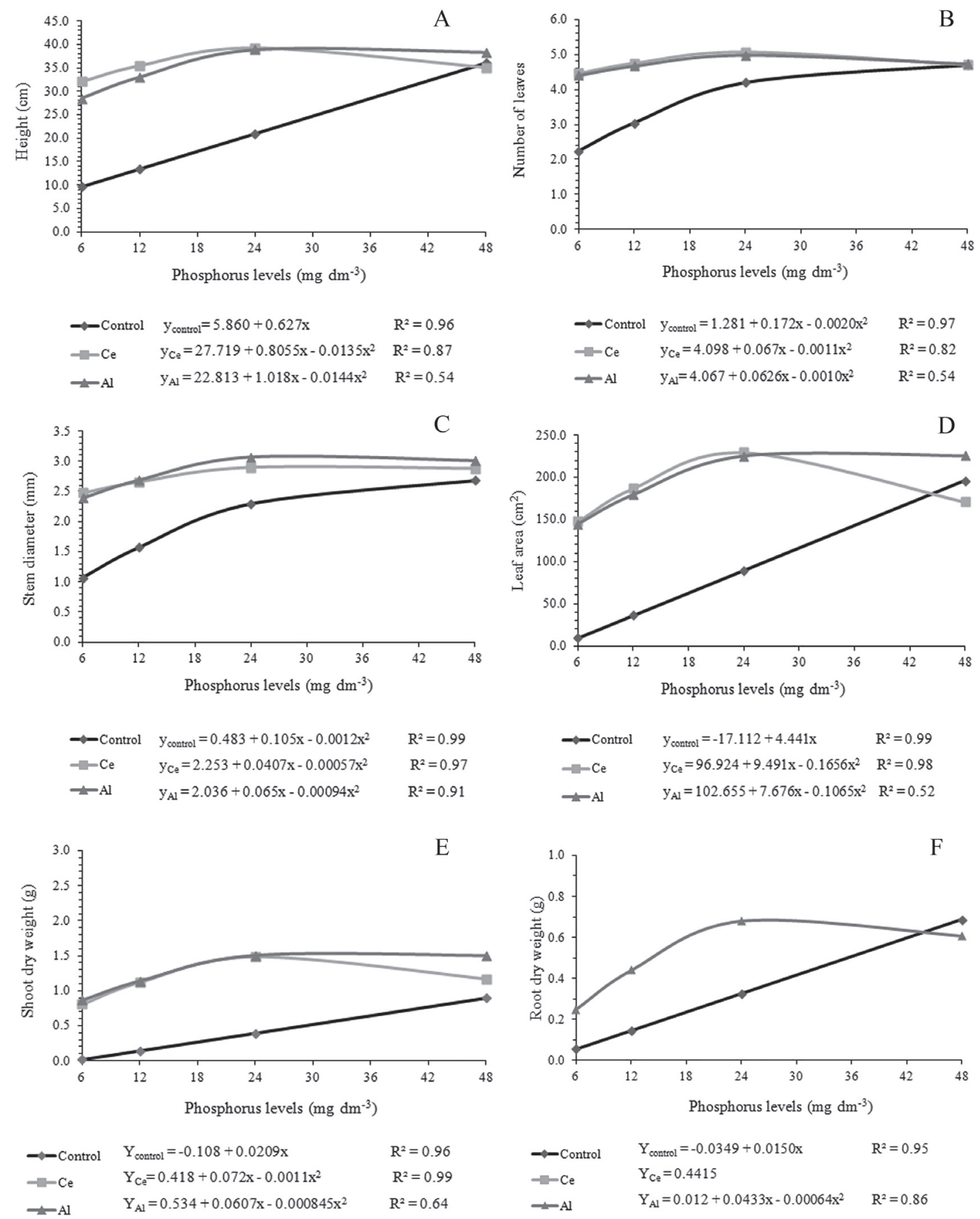

Figure 1. Plant height (A), number of leaves (B), stem diameter (C), leaf area (D), shoot dry weight (E), and root dry weight (F) of Schinopsis brasiliensis Engl. individuals inoculated with Claroideoglomus etunicatum (Ce) or Acaulospora longula (Al), and non-inoculated, grown with different levels of phosphorus (P6, P12, P24, and P48) in a glasshouse for 135 days. 
number of spores produced by $A$. longula did not significantly differ among the different $\mathrm{P}$ treatments. However, sporulation of C. etunicatum peaked after adding $20.18 \mathrm{mg} \mathrm{dm}^{-3}$ of P. Similarly to mycorrhizal colonization, the number of spores was higher for $C$. etunicatum than for A. longula.

Mello et al. (2008) observed that colonization of A. mearnsii seedlings by AMF Glomus clarum and C. etunicatum does not decrease even at high levels of $\mathrm{P}$, although sporulation decreases. Several studies have reported a lack of correlation between mycorrhizal colonization and sporulation (Machineski et al.2011), which is similar to our results, where only the production of C. etunicatum spores was observed to respond to high P levels (Fig. 2B). According to Sanders (2004) and Balota et al. (2011a), different mycorrhizal isolates have different life strategies, which primarily depends on the plant host.

The decrease in mycorrhizal response with increasing soil P levels observed here showed the beneficial effect that mycorrhization confers when the level of $\mathrm{P}$ available is sub-optimal. The response to mycorrhization improved with lower levels of $\mathrm{P}$ addition (Fig. 3). Without $\mathrm{P}$ addition
(P6), plants were highly responsive to mycorrhization with both C. etunicatum (94\%) and A. longula (92\%). Mycorrhizal response gradually decreased with increasing $P$ additions for both C. etunicatum (88, 64.4 and 10.3\%) and A. longula (90, 62.2 and $31.7 \%$ ). At the highest $\mathrm{P}$ level (P48), responsiveness to mycorrhization was marginal with $C$. etunicatum and moderate with A. longula. Similar levels of responsiveness were observed in plant species characteristic of Caatinga secondary forest, such as A. macrocarpa and Caesalpinia ferrea (Sugai et al. 2011), and in climax species from other biomes, such as Luehea grandiflora, Senna spectabilis, Tibouchina granulosa, Cordia trichotoma, Leucaena leucocephala, Senna macranthera, Cedrella fissilis, and Myrsine umbellata (Siqueira \& Saggin-Júnior 2001).

In this study, we also quantified macro- (Fig. 4A-F) and micronutrient (Figs. 5A-F) content in S. brasiliensis plants. Highest levels of soil P availability (P48) resulted in greater uptake of this element and enhanced uptake of other elements such as $\mathrm{N}, \mathrm{K}, \mathrm{Ca}, \mathrm{Mg}, \mathrm{B}, \mathrm{Cu}, \mathrm{Mn}$, and $\mathrm{Zn}$ in non-inoculated plants (Figs. 4A, C-E, 5A-B, and D-E, respectively), accelerating their development (Fig. 1). Efficiency in the acquisition

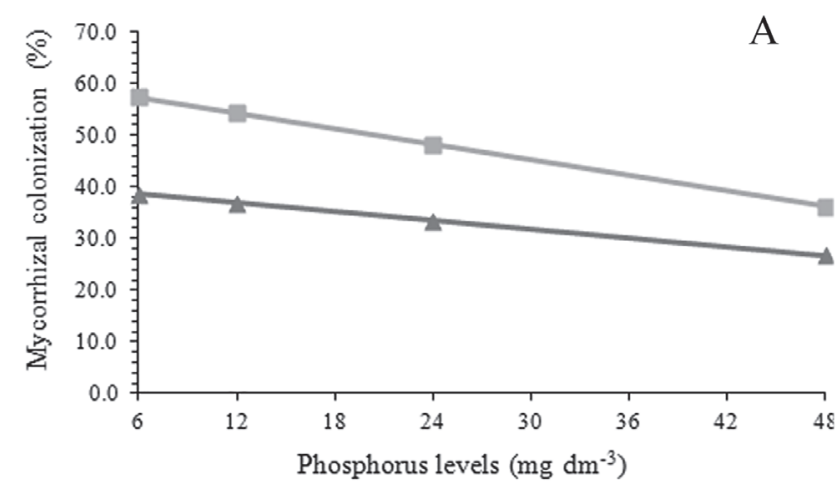

$$
\begin{array}{lll}
-\mathrm{Ce} & \mathrm{y}_{\mathrm{Ce}}=60.423-0.506 \mathrm{x} & \mathrm{R}^{2}=0.91 \\
-\mathrm{Al} & \mathrm{y}_{\mathrm{Al}}=40.313-0.283 \mathrm{x} & \mathrm{R}^{2}=0.90
\end{array}
$$

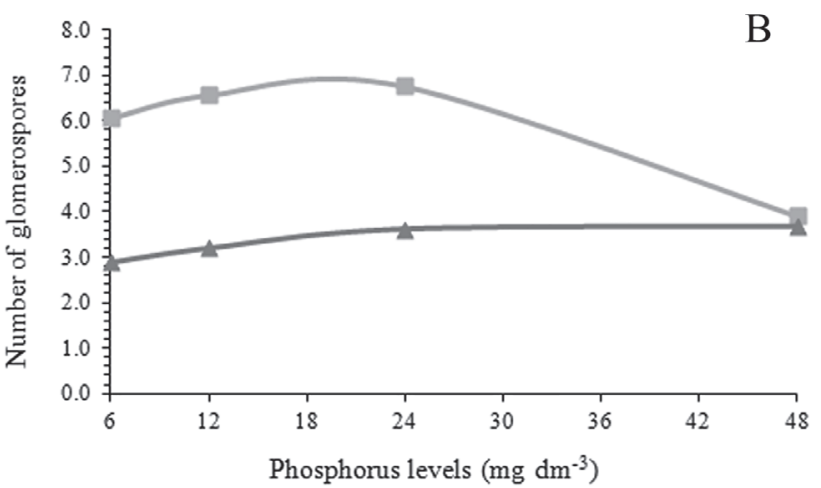

$$
\begin{array}{lll}
-\mathrm{Ce} & \mathrm{y}_{\mathrm{Ce}}=5.284+0.1512 \mathrm{x}-0.0037 \mathrm{x}^{2} & \mathrm{R}^{2}=0.91 \\
-\mathrm{Al} & \mathrm{y}_{\mathrm{Al}}=2.531+0.066 \mathrm{x}-0.00089 \mathrm{x}^{2} & \mathrm{R}^{2}=0.90
\end{array}
$$

Figure 2. Mycorrhizal colonization (\%) (A) and number of glomerospores (B) on the rhizosphere of Schinopsis brasiliensis Engl. plants inoculated with Claroideoglomus etunicatum (Ce) or Acaulospora longula (Al), or non-inoculated, grown with different levels of phosphorus (P6, P12, P24, and P48) in a glasshouse for 135 days.

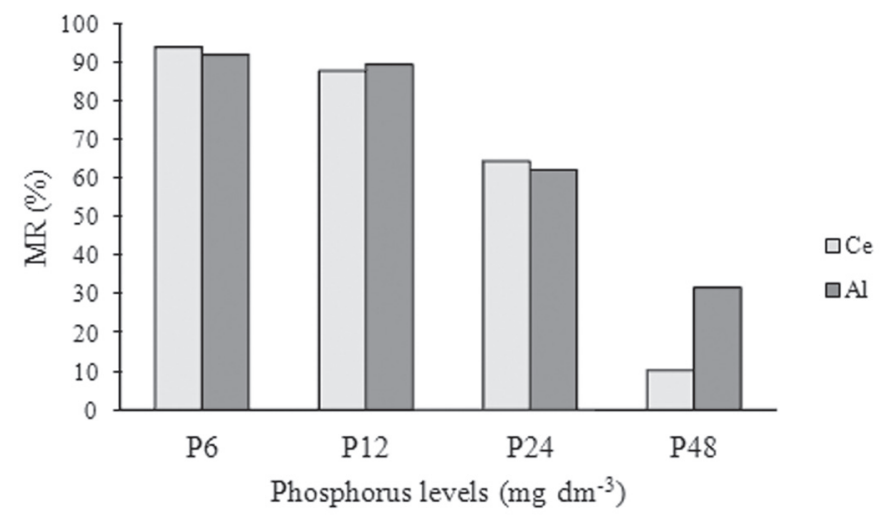

Figure 3. Mycorrhizal response (MR) of Schinopsis brasiliensis Engl. plants in association with Claroideoglomus etunicatum (Ce) or Acaulospora longula (Al) in soils with increasing phosphorus levels (P6, P12, P24, and P48) grown in a glasshouse for 135 days. 
of macro- and micronutrients, independently of the amount of $\mathrm{P}$ added to the soil, has been also described for 14 out of 31 mycorrhizal tropical tree species analyzed (Carneiro et al. 1996), in particular for P, Ca and S.

Plants inoculated with C. etunicatum showed a linear decrease in $\mathrm{K}, \mathrm{B}, \mathrm{Cu}, \mathrm{Zn}$, and $\mathrm{Na}$ contents with increasing
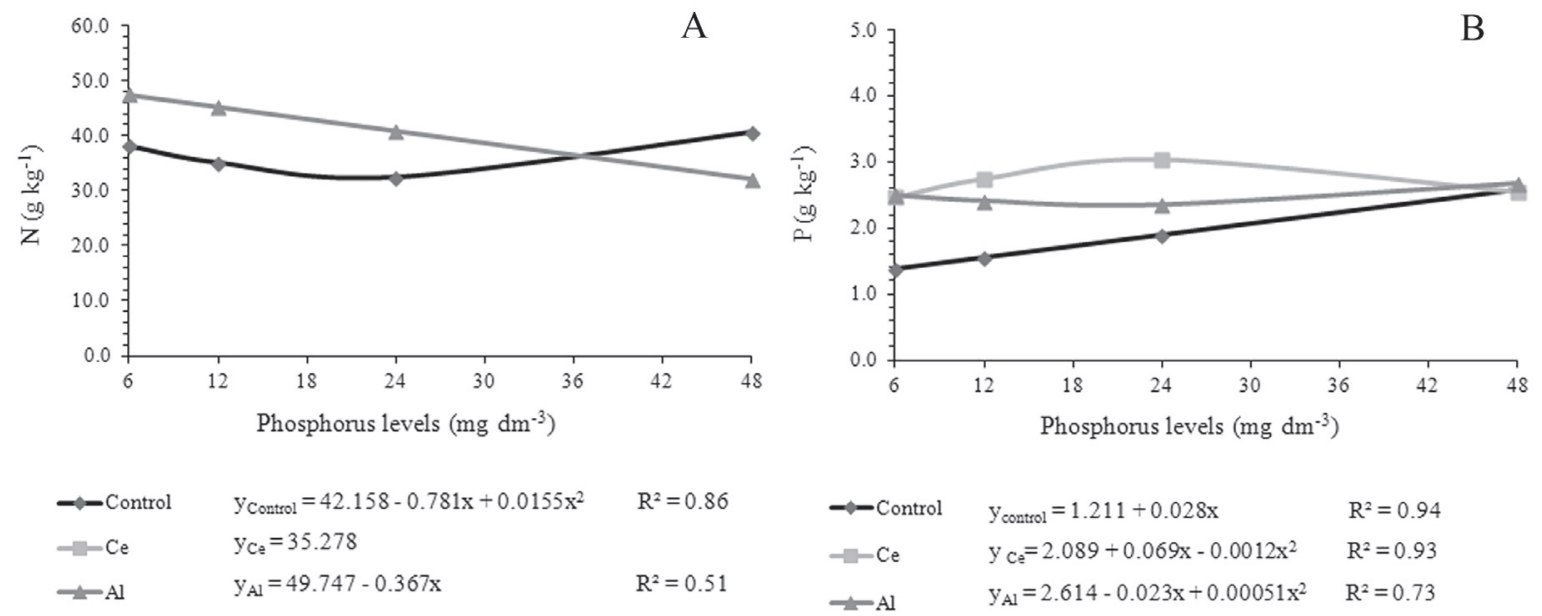

$y_{\text {control }}=1.211+0.028 x$
$y_{c_{e}}=2.089+0.069 x-0.0012 x^{2}$
$y_{A d}=2.614-0.023 x+0.00051 x^{2}$

$\mathrm{R}^{2}=0.94$
$-\mathrm{Al}$

$R^{2}=0.93$

$\mathrm{R}^{2}=0.73$

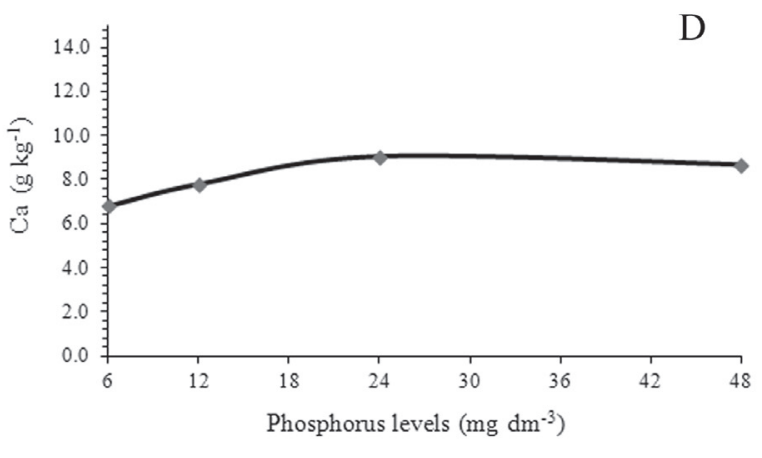

P levels (Figs. 4C, 5A-B, and E-F, respectively); a similar response was found for $\mathrm{N}, \mathrm{Mg}, \mathrm{Cu}$, and $\mathrm{Zn}$ in plants inoculated with A. longula (Figs. 4A, E, 5B, and E, respectively). Plants presenting favorable nutritional status develop mechanisms to reduce the development and/or activity of root AMF to reduce mycorrhization and its associated energy costs
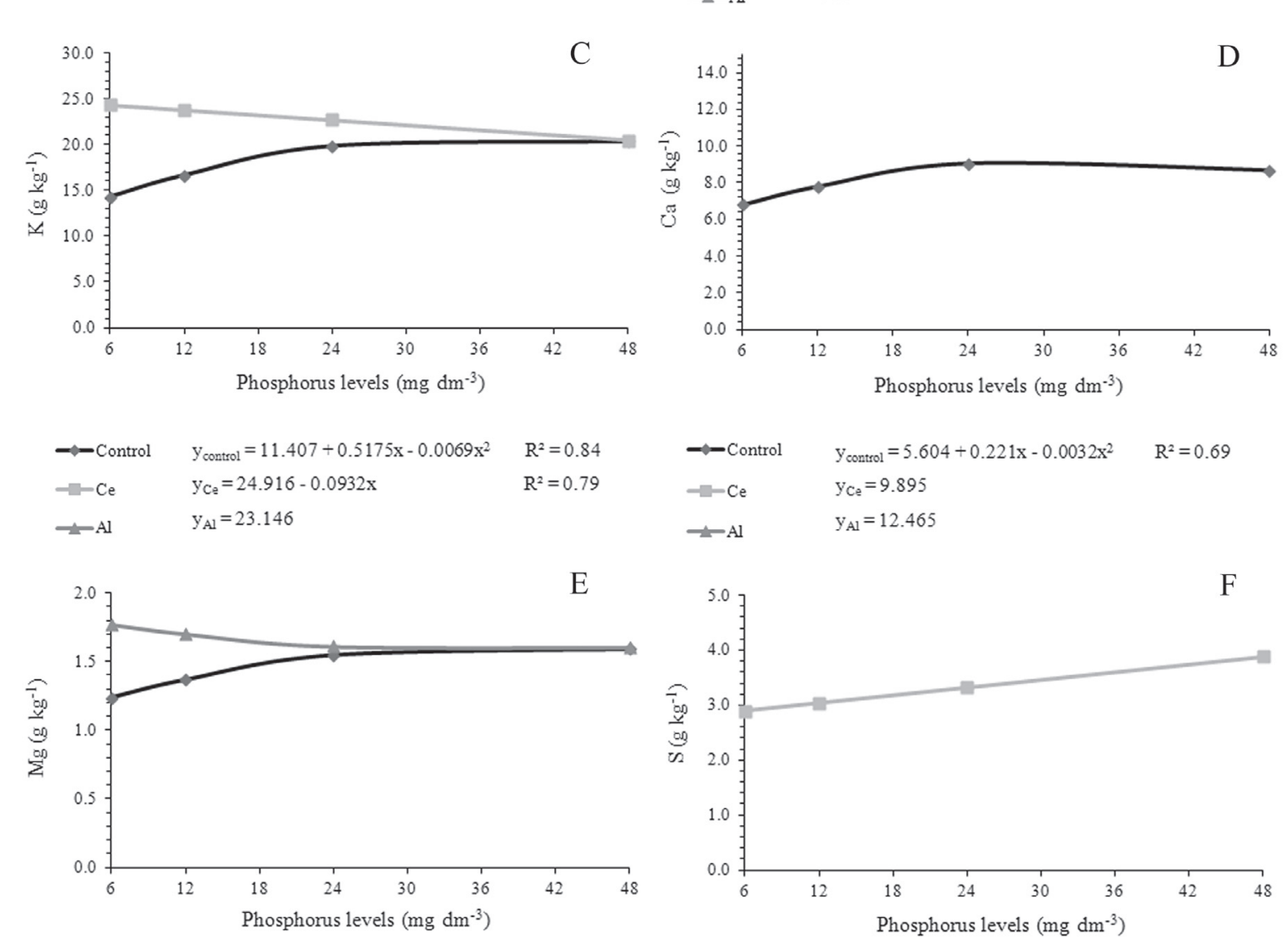

$$
\begin{array}{lll}
- \text { Control } & \mathrm{y}_{\text {control }}=1.075+0.0287 \mathrm{x}-0.00037 \mathrm{x}^{2} & \mathrm{R}^{2}=0.85 \\
-\mathrm{Ce} & \mathrm{y}_{\mathrm{Ce}}=1.576 & \\
-\mathrm{Al} & \mathrm{y}_{\mathrm{Al}}=1.848-0.014 \mathrm{x}+0.00020 \mathrm{x}^{2} & \mathrm{R}^{2}=0.87
\end{array}
$$

$$
\begin{array}{lll}
\rightarrow \text { Control } & \mathrm{y}_{\text {control }}=2.308 & \\
- \text { Ce } & y_{\mathrm{Ce}}=2.751+0.0235 \mathrm{x} & \mathrm{R}^{2}=0.92
\end{array}
$$

Figure 4. Macronutrient content [N (A), P (B), K (C), Ca (D), Mg (E) and S (F), in g kg ${ }^{-1}$ ] in shoots of Schinopsis brasiliensis Engl. plants inoculated with Claroideoglomus etunicatum (Ce) or Acaulospora longula (Al), and non-inoculated, grown with different levels of phosphorus (P6, P12, P24, and P48) in a glasshouse for 135 days. 

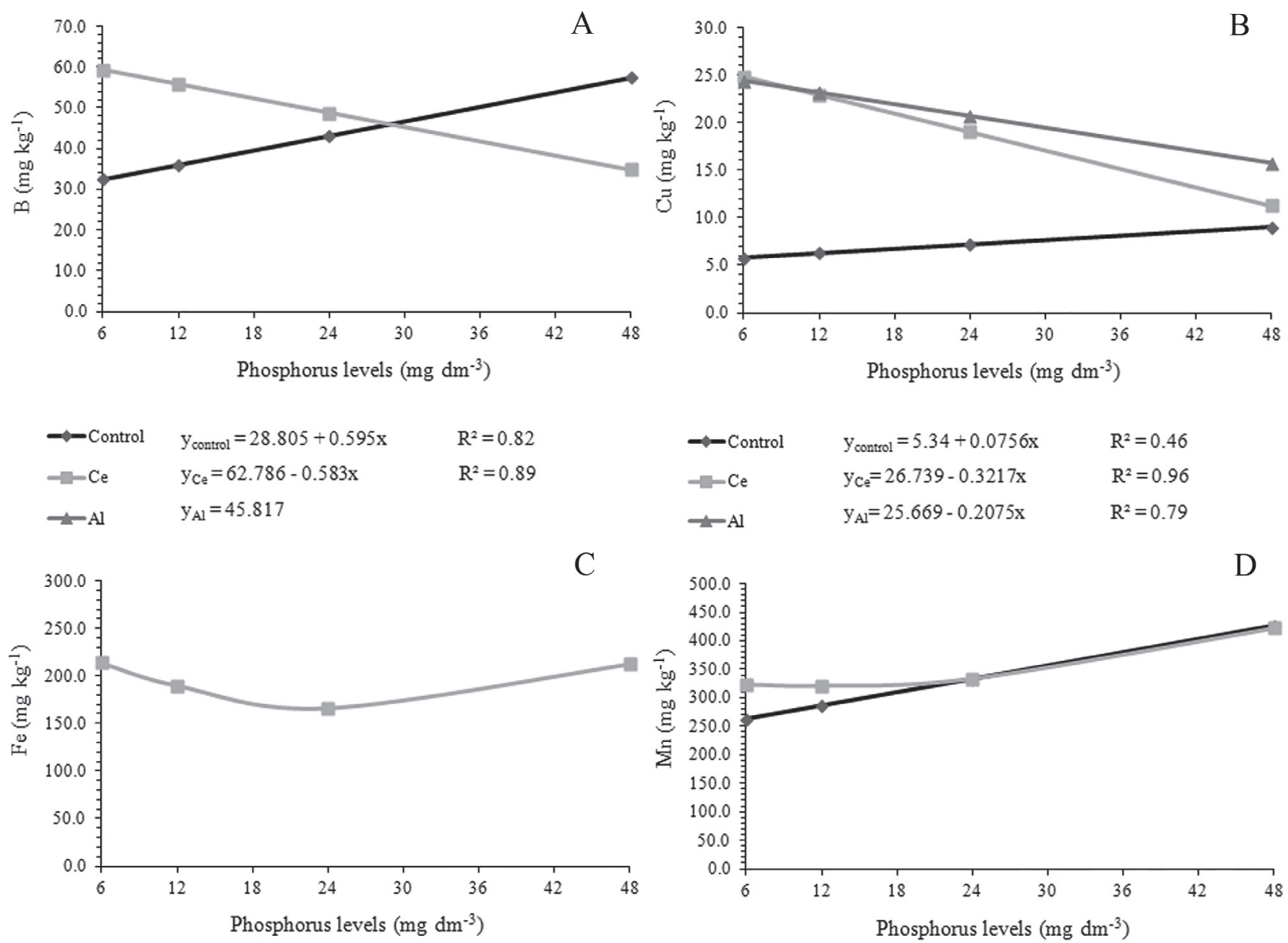

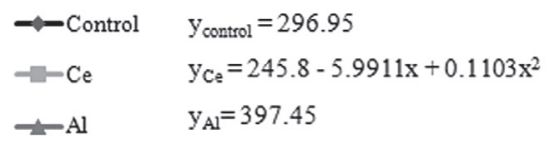

$\mathrm{R}^{2}=0.61$

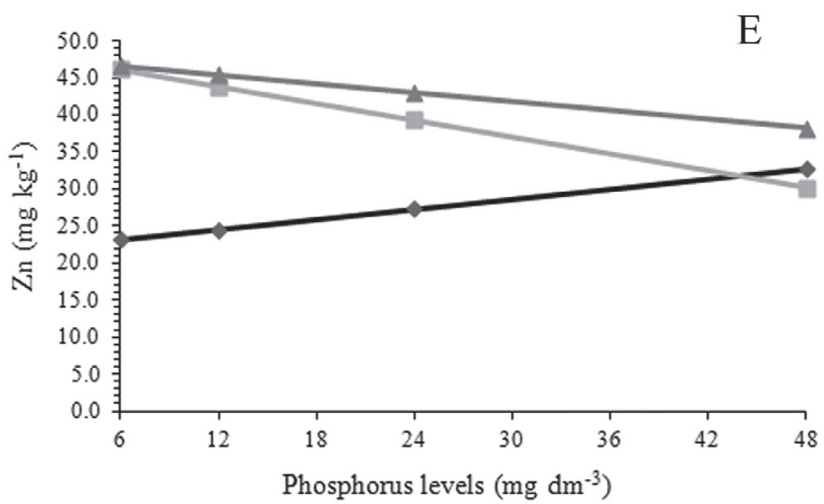

$\begin{array}{lll}\rightarrow \text { Control } & \mathrm{y}_{\text {control }}=21.817+0,228 \mathrm{x} & \mathrm{R}^{2}=0.93 \\ -\mathrm{Ce} & \mathrm{y}_{\mathrm{Ce}}=48.452-0,382 \mathrm{x} & \mathrm{R}^{2}=0.90 \\ -\mathrm{Al} & \mathrm{y}_{\mathrm{Al}}=47.843-0.199 \mathrm{x} & \mathrm{R}^{2}=0.67\end{array}$
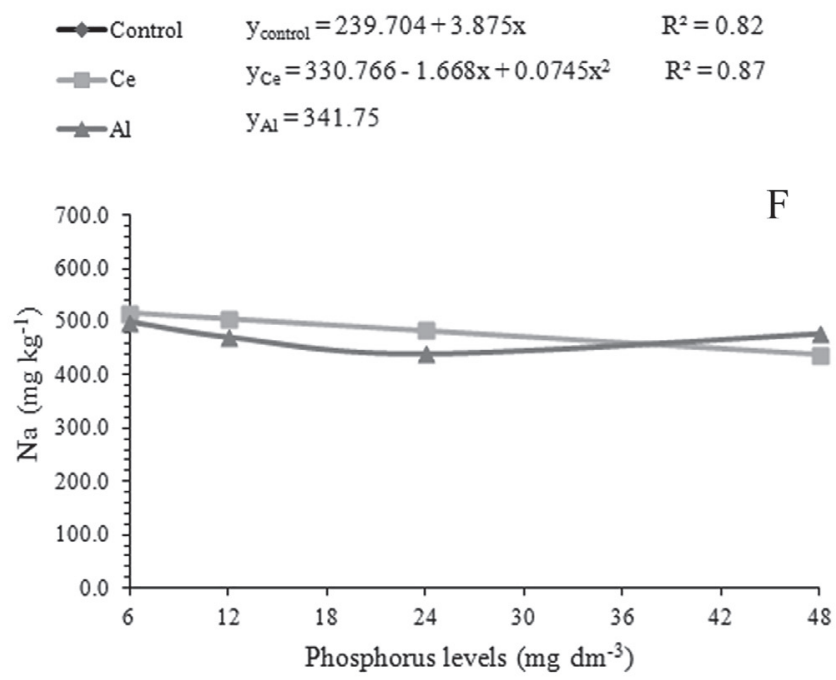

$\begin{array}{lll}\rightarrow-\text { Control } & \mathrm{y}_{\text {control }}=428.358 & \\ -\mathrm{Ce} & \mathrm{y}_{\mathrm{Ce}}=528.017-1.862 \mathrm{x} & \mathrm{R}^{2}=0.54 \\ -\mathrm{Al} & \mathrm{y}_{\mathrm{Al}}=535.644-6.780 \mathrm{x}+0.1157 \mathrm{x}^{2} & \mathrm{R}^{2}=0.55\end{array}$

Figure 5. Micronutrient content [B (A), Cu (B), Fe (C), Mn (D) and $\mathrm{Zn}(\mathrm{E})$, in $\mathrm{mg} \mathrm{kg}^{-1}$ ] and Na (F; in mg kg $\mathrm{kg}^{-1}$ ) in shoots of Schinopsis brasiliensis Engl. plants inoculated with Claroideoglomus etunicatum (Ce) or Acaulospora longula (Al), and non-inoculated, grown with different levels of phosphorus (P6, P12, P24, and $\mathrm{P} 48$ ) in a glasshouse for 135 days. 
(Smith\& Read 2008). The lower nutrient accumulation observed might be related to a decrease in the need for a symbiotic association due to higher $\mathrm{P}$ availability; this is reflected in the decrease of mycorrhizal colonization. This pattern has been also observed in M. emarginata plants (Balota et al. 2011a).

$\mathrm{S}$ and Fe were positively related to higher levels of $\mathrm{P}$ addition in plants inoculated with C. etunicatum (Figs. 4F,5C respectively). These elements play important roles in aminoacid, protein, and chlorophyll synthesis and therefore in photosynthetic activity (Dechen \& Nachtigall 2007; Hansch \& Mendel 2009). Comparing mycorrhizal plants to nonmycorrhizal control individuals for each $\mathrm{P}$ level, we observed higher contents of $\mathrm{P}, \mathrm{Cu}$, and $\mathrm{Zn}$ in inoculated plants up to the P24 treatment (Figs. 4B, 5B, and E, respectively).

Low $\mathrm{P}$ availability is characteristic of Brazilian soils; in addition, the use of fertilizers can substantially impact the total costs associated with agricultural practices (Carneiro et al. 2009). The present results showed that mycorrhizal inoculation could represent an efficient alternative to obtain S. brasiliensis seedlings with an adequate nutrient and developmental status while reducing costs related to the use of $\mathrm{P}$ fertilizers, possibly guaranteeing better seedling establishment in the field.

In conclusion, Schinopsis brasiliensis plants responded to $\mathrm{P}$ fertilization, and showed a linear correlation between the level of $\mathrm{P}$ fertilization and both growth and nutrient content. This species was also highly responsive to mycorrhization, benefiting from the inoculation with Claroideoglomus etunicatum and Acaulospora longula in terms of vegetative development, especially in soils with low $\mathrm{P}$ concentrations. Considering that high $\mathrm{P}$ levels decreased mycorrhizal colonization and sporulation, particularly for C. etunicatum isolates, mycorrhizal inoculation can be recommended in substitution of $\mathrm{P}$ fertilization in soils with low $\mathrm{P}$ availability.

\section{Acknowledgments}

The authors thank the Fundação de Amparo à Ciência e Tecnologia de Pernambuco (FACEPE) (APQ 1265-2.03/10) for the Master (Teixeira-Rios, T.) and Ph.D. (Silva, E.M.) scholarships, the Conselho Nacional de Desenvolvimento Científico e Tecnológico (CNPq) (Proc. 562637/2010-9) for the Ph.D. (Oliveira, J.R.G.) and PQ (Yano-Melo, A.M.) scholarships, the work teams of the Univasf/CCA Microbiology and Embrapa Semiárido Biotechnology laboratories for the use of their facilities and Dr. Geraldo Milanez de Resende for help with the statistical analyses.

\section{References}

Andrade MW, Lima EA, Rodal MJN, Encarnação CRF, Pimentel RMM. 2009. Influência da precipitação na abundância de populações de plantas da Caatinga.Revista de Geografia 26:16-184.
Balota EL, Machineski O, Stenzel NMC. 2011a. Resposta da acerola à inoculação de fungos micorrízicos arbusculares em solo com diferentes níveis de fósforo. Bragantia 70: 166-175.

Balota EL, Machineski O, Truber PV, Scherer A, Souza FS. 2011b. Physic nut plants present high mycorrhizal dependency under conditions of low phosphate availability. Brazilian Society of Plant Physiology 23: 33-44.

Carneiro MAC, Siqueira JO, Davide AC, Gomes LJ, Curi N, Vale FR. 1996. Fungo micorrízico e superfosfato no crescimento de espécies arbóreas tropicais. Scientia Forestalis 50: 21-36.

Carneiro MAC, Siqueira JO, Davide AC. 2004. Fósforo e inoculação com fungos micorrízicos arbusculares no estabelecimento de mudas de embaúba (Cecropia pachystachya Trec). Pesquisa Agropecuária Tropical 34: 119-125.

Carneiro RFV, Evangelista AR, Araújo ASF. 2009. Crescimento vegetativo e aquisição de nutrientes pela alfafa em resposta à micorriza e doses de fósforo. Revista Brasileira de Ciências Agrárias 4: 267-273.

Carvalho ECD, Souza BC, Trovão DMBM. 2012. Ecological succession in two remnants of the Caatinga in the semi-arid tropics of Brazil. Revista Brasileira de Biociências 10: 13-19.

Dechen AR, Nachtigall GR. 2007. Elementos requeridos à nutrição de plantas.In: NovaisRF, Alvarez VVH, Barros NF, Fontes RLF, Cantarutti RB,Neves JCL. (eds.) Fertilidade do Solo.Viçosa, SBCS/ UFV. p 92-132.

Freitas MSM, Martins MA, Carvalho AJC. 2008. Produção de biomassa e teores de macronutrientes da tanchagem (Plantago major L.) em resposta a adubação fosfatada e micorrizas arbusculares. Revista Brasileira de Plantas Medicinais 10: 31-37.

Gerdemann JW, Nicolson TH. 1963. Spores of mycorrhizal Endogone species extracted from soil by wet sieving and decanting. Transactions of the British Mycological Society 46: 235-244.

Giovanetti M, Mosse B. 1980. An evaluation of techniques for measuring vesicular arbuscular mycorrhizal infection in roots. New Phytologist 84: 489-500.

Goto BT, Silva GA, Yano-Melo AM, Maia LC. 2010. Checklist of the arbuscular mycorrhizal fungi (Glomeromycota) in the Brazilian semiarid. Mycotaxon 113: 251-254.

Habte M, Manjunath A. 1991. Categories of vesicular-arbuscular mycorrhizal dependency of host species. Mycorrhiza 1:3-12.

Hansch R, Mendel RR. 2009. Physiological functions of mineral micronutrients $(\mathrm{Cu}, \mathrm{Zn}, \mathrm{Mn}, \mathrm{Fe}, \mathrm{Ni}, \mathrm{Mo}, \mathrm{B}, \mathrm{Cl})$. Current Opinion in Plant Biology 12: 259-266.

Heijden GAVD, Boller T, Wiemken A, Sanders IR. 1998. Diferent Arbuscular Mycorrhizal fungal species are potencial determinants of plant community structure. Ecology 79: 2082-2091.

Janos DP. 2007 Plant responsiveness to mycorrhizas differs from dependence upon mycorrhizas. Mycorrhiza 17: 75-91.

Jenkins WR. 1964. A rapid centrifugal-flotation technique for separating nematodes from soil. Plant Disease Report 48: 692.

Lacerda KAP, Silva MMS, Carneiro MAC, Reis EF, Saggin-Júnior OJ. 2011. Fungos micorrízicos arbusculares e adubação fosfatada no crescimento inicial de seis espécies arbóreas do cerrado. CERNE 17: 377-386.

Machineski O, Balota EL, Souza JRP. 2011. Resposta da mamoneira a fungos micorrízicos arbusculares e a níveis de fósforo. Semina: Ciências Agrárias 32: 1855-1862.

Maia LC, Silva GA, Yano-Melo AM, Goto BT. 2010. Fungos micorrízicos arbusculares no bioma Caatinga. In: Siqueira JO, Souza FA, Cardoso EJBN, Tsai SM. (eds.) Micorrizas: 30 anos de pesquisas no Brasil. Lavras, UFLA. p. 311-339.

Mello AH, Kaminski J, Antoniolli ZI, et al. 2008. Influência de substratos e fósforo na produção de mudas micorrizadas de Acacia Mearnsii De Wild. Ciência Florestal 18: 321-327.

Oliveira RLC, Lins Neto EMF, Araujo EL, Albuquerque UP. 2007. Conservation priorities and population structure of woody medicinal plants in an area of caatingavegetation (Pernambuco State, NE Brazil). Environmental Monitoring and Assessment 132: 189-206.

Pasqualine D, Uhlmann A, Sturmer SL. 2007. Arbuscular mycorrhyzal fungal communities influence growth and phosphorus concentration of woody plants species from the Atlantic rain forest in South Brazil. Forest Ecology and Management 245: 148-155. 
Phillips JM, Hayman DS. 1970. Improved procedures for clearing roots and staining parasitic and vesicular arbuscular mycorrhizal fungi for rapid assessment of infection. Transactions of British Mycological Society 55: 158-161.

Plenchette C, Fortim JA, Furlan V. 1983. Growth responses of several plant species to mycorrhizae in a soil of moderate P-fertility. I: Mycorrhizal dependency under field conditions. Plant and Soil 70: 199-209.

Sanders IR. 2004. Intraspecific genetic variation in arbuscular mycorrhizal fungi and its consequences for molecular biology, ecology, and development of inoculum. Canadian Journal of Botany 82: 1057-1062.

Santos JP, Araújo EL, Albuquerque UP. 2008.Richness and distribution of useful woody plants in the semi-arid region of northeastern Brazil. Journal of Arid Environments 72: 652-666.

Silva FC. 1999. Manual de análises químicas de solos, plantas e fertilizantes. Brasília, Embrapa.

Siqueira JO, Saggin-Júnior OJ. 2001. Dependency on arbuscular mycorrhizal fungi and responsiveness of some Brazilian native woody species. Mycorrhiza 11: 245-255.
Smith SE, Read DJ. 2008. Mycorrhizal Symbiosis. San Diego, Academic Press.

Sugai MAA, Collier LS, Saggin-Júnior OJ. 2011. Inoculação micorrízica no crescimento de mudas de angico em solo de cerrado. Bragantia 70: 416-423.

Tabarelli M, Silva JMC. 2003. Áreas e ações prioritárias para a conservação da biodiversidade da caatinga. In: Leal IR, Tabarelli M, Silva JMC. (eds.) Ecologia e conservação da caatinga. Recife: Editora Universitária da UFPE. p. 777-796.

Teixeira-Rios T, Souza RG, Maia LC, Oehl F, Lima CEP. 2013. Arbuscular mycorrhizal fungi in a semi-arid, limestone mining-impacted área of Brazil. Acta Botanica Brasilica 27: 688-693.

Weber OB, Souza CM, Gondin DF, et al. 2004. Inoculação de fungos micorrízicos arbusculares e adubação fosfatada em mudas de cajueiro-anãoprecoce. Pesquisa Agropecuária Brasileira 39: 477-483.

Zhu XC, Song FB, Liu SQ, Liu TD, Zhou X. 2012. Arbuscular mycorrhizae improves photosynthesis and water status of Zea mays L. under drought stress. Plant Soil and Environment 58: 186-191. 